\title{
PENGARUH PENAMBAHAN IMIDAZOLINE TERHADAP TINGKAT KOROSI PIPA GAS LEPAS PANTAI
}

\author{
Imam Sujarwo*, Rita Dwi Ratnani dan Laeli Kurniasari \\ Jurusan Teknik Kimia, Fakultas Teknik, Universitas Wahid Hasyim Semarang \\ Jl. Menoreh Tengah X/22, Sampangan, Semarang 50236 \\ *Email: isujarwo@yahoo.com
}

\begin{abstract}
Abstrak
Korosi menjadi masalah yang terpenting dalam industri dan perminyakan. Proses pencegahan dan kontrol korosi sangat penting dilakukan untuk mengurangi efek korosi yang besar yaitu kebocoran instalasi pipa. Kandungan ion maupun senyawa terlarut seperti chloride yang tinggi, sufida terlarut, carbonat maupun bi-carbonat merupakan salah satu faktor yang menyebabkan terjadinya korosi. Hal lain yang juga dapat menimbulkan terjadinya korosi pada logam adalah aktifitas mikroba Sulfur Reduction Bacteria (SRB). Untuk mengendalikan korosi dalam pipa umumnya ditambahkan senyawa penghambat korosi (inhibitor). Penambahan anti korosi imidazoline dengan kombinasi surfaktan dilakukan untuk mencegah adanya proses korosi pada logam pipa produksi. Penelitian ini bertujuan untuk mengetahui aktifitas mikroba dan potensi korosi yang di timbulkan dari aktifitasnya, serta untuk mengetahui efektifitas dari penghambat korosi (imidazoline) yang di tambahkan pada konsentrasi 50 ppm-150-ppm kedalam aliran gas hidrokarbon dengan kandungan $\mathrm{CO}_{2}$ dalam gas $0.715 \%$ mol, chloride $700 \mathrm{mg} / \mathrm{lt}$. Pengukuran dan evaluasi dilapangan dilakukan dengan menggunakan metoda ER (Electical Resistant). Efektifitas terbaik imidazoline derivate pada gas terseparasi minimum $16.33 \%$ dan maksimum efisensi mencapai $76.67 \%$.
\end{abstract}

Kata kunci: efisiensi inhibitor, imidazoline, inhibitor korosi, korosi

\section{PENDAHULUAN}

Gas bumi adalah sumber energi dan sumber bahan baku pembuatan pupuk urea yang memiliki peran penting di Indonesia saat ini. Produksi gas bumi Indonesia berdasarkan statistik tahun 2014 mencapai 2,99 tscf yang digunakan sebagai bahan bakar pembangkit listrik dan industri petrokimia seperti pembuatan pupuk urea, methanol dan industri kimia lain. Dalam kegiatan produksi suatu sumur eksplorasi menghasilkan tiga fluida yaitu air, minyak dan gas. Ketiga fluida tersebut mengalir dari recervoir menuju permukaan melalui peralatan subsurface (tubing, artificial lift). Laju aliran menimbulkan friksi antara fluida dengan dinding pipa. Laju alir tersebut menyebabkan perubahan tekanan dan dapat pula menyebabkan fenomena korosi serta pengendapan (scale). Kedua hal ini merupakan masalah umum yang di terjadi di lapangan produksi minyak dan gas.

Korosi adalah proses elektrokimia yang terjadi antara katoda dan anoda dengan pelepasan elektron (anoda) dan penerimaan elektron (katoda). Sedangkan scale adalah terbentuknya endapan senyawa ion (kation/ anion) yang terjadi karena adanya ion tersebut dalam air. Kandungan air yang tinggi dalam komposisi gas menimbulkan efek korosi yang lebih besar dalam pipa selain senyawa anorganik, seperti $\mathrm{H}_{2} \mathrm{~S}, \mathrm{CO}_{2}$,serta efek $\mathrm{pH}$ juga menambah potensi korosi di dalam pipa (Ikeda dkk, 1985). Adanya $\mathrm{H}_{2} \mathrm{~S}$ dalam gas akan meningkatkan $\mathrm{pH}$ dan korosi logam. Hidogen sulfida bisa di hasilkan juga oleh adanya aktivitas bakteri sulfat yang mereduksi senyawa sulfat menjadi sulfida yang akan menambah fenomena korosi pipa (Dennis dan Garrelfs, 2014). Kandungan $\mathrm{CO}_{2}$ dan efek pembentukan formasi karbonat antara $\mathrm{Fe}$ (besi) dengan karbonat membentuk besi karbonat, akan menambah laju korosi (Kermani dan Morshed 2003). Untuk mengendalikan korosi dalam pipa umumnya ditambahkan senyawa penghambat korosi (inhibitor). Adapun analisa lempeng baja (coupon) atau probe dilakukan sebagai kontrol untuk memprediksi pertumbuhan korosi pada pipa.

Imidazoline adalah senyawa organik dengan gugus rantai nitrogen atau masuk dalam senyawa amida atau garam amina. Senyawa ini sering digunakan sebagai inhibitor korosi pipa. Imidazolin umumnya digunakan pada lingkungan yang memiliki kandungan $\mathrm{CO}_{2}$ dalam jumlah tertentu. Variasi dari penggunaan inhibitor dengan penambahan surfantant (Jovancicevic dkk, 1999) menghasilkan efektifitas yang baik untuk mengurangi korosi dan pada 150 ppm mencapai efektifitas optimum. Adapun penelitian ini bertujuan untuk mengevaluasi penggunaan inhibitor 
imidazoline terhadap tingkat korosi pipa gas lepas pantai.

\section{METODE PENELITIAN}

\section{Bahan Penelitian}

Bahan dan alat pengecekan bakteri sulfat digunakan seperangkat alat sanicheck. Sanicheck terdiri dari media agar dalam tabung tanam (applicator) dan mineral oil. Bahan yang di gunakan dalam kotrol anti korosi adalah inhibitor dari derivate imidazolin. Imidazoline berasal dari startbornchem dengan konsentrasi $<20 \%$, dan surfactant dari senyawa amonium kurtener dan ester fosfat.

\section{Peralatan}

Peralatan yang di gunakan untuk analisa bakteri sanicheck sedangkan untuk alat yang digunakan sebagai analisa korosi adalah detektor korosi

\section{Prosedur Penelitian}

\section{Pengecekan aktivitas mikroba}

Pengecekan adanya proses korosi dari kualitas kandungan air maka dilakukan pengecekan tentang sampel air tes sanicheck untuk mengetahui aktivitas dari mikroba dalam fluida.Pengecekan dilakukan dengan cara pengambilan $10 \mathrm{ml}$ dari sampel air pada separator dan pipa produksi. Penggunaan paket alat pengetesan bakteri (Sanicheck) dengan memasukan aplikator kedalam sampel dan menanamkan pada media tanam tabung. Penyimpan di lakuka pada suhu minimal $5 \mathrm{C}$ dan pengmatan selama 5 hari.

\section{Pengecekan nilai korosi}

Sebelum melakukan pengamatan dan penambahan jumlah inhibitor dilakukan perhitungan nilai dari inhibitor dalam pengetesan dalam kadar 50 ppm, 100 ppm, 150 ppm, dan pengambilan data dilakukan selama 15 hari untuk mendapatkan data minimal dari efek korosi dan efisiensi dari inhibitor dan probe. Pengambilan data dilakukan pada 4 titik sampel pengambilan korosi atau SCP (Sample Corrosion Probe) yaitu pada titik SCP 001, 002, 003 dan 004 dengan jumlah waktu dan konsentrasi yang sama.

\section{HASIL DAN PEMBAHASAN Pengamatan aktifitas bakteri}

Berdasarkan pada pengamatan pada Gambar 1a dan $1 \mathrm{~b}$, batas pada Tabel analisa bakteri anerob terbaca pada $10^{2} / \mathrm{ml}$ dengan interpretasi dari nilai pertumbuhan tersebut sangat rendah. Koloni yang tumbuh di sekitar media dan menghitam pada hari ke-5 sejumlah $10^{1}-10^{2} / \mathrm{ml}$ dan jumlah yang sama di temukan pada pengamatan di pipa. Dari kedua hasil pengamatan terlihat adanya aktifitas mikroba dengan terlihat adanya koloni mikroba dalam sistem fluida.

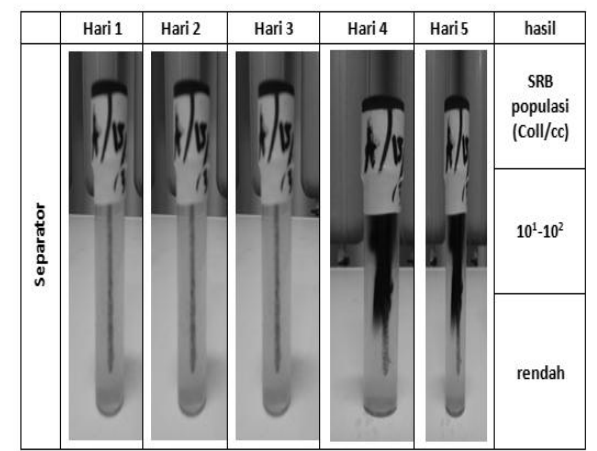

\section{Gambar 1a. Hasil uji aktifitas mikroba sulfur pada bagian separator}

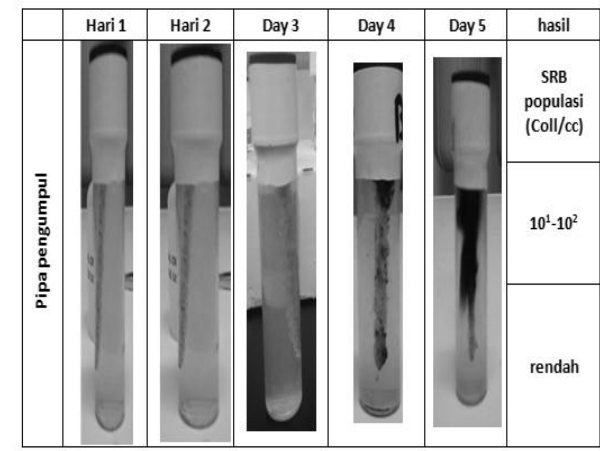

Gambar 1b. Hasil uji aktifitas mikroba sulfur pada bagian pipa pengumpul

Pertumbuhan mikroba pada permukaan pipa dan aktifitasnya akan dapat membentuk scale yang dapat meningkatkan laju korosi pada logam. Akifitas lain adalah dengan terbentuknya $\mathrm{H}_{2} \mathrm{~S}$ sehingga berpotensi mempengaruhi perubahan $\mathrm{pH}$ dan percepatan korosi. Tipe korosi yang di sebabkan oleh mikroba mempunyai tingkat korosifitas yang bervariasi dari tingkat rendah sampai tingkat tingi mencapai 16 mpy. Aktifitas dan tanda korosi ini bisa diketahui dengan adanya deposit pada titik korosi.

Jumlah yang rendah dari hasil pengamatan mikroba tidak akan terlalu berpengaruh apabila pengolahan dari pemisahan kondensasi air pada proses produksi sangat baik. Lain halnya apabila pada proses terjadi kondisi sebaliknya, maka dapat di mungkinkan adanya akumulasi 
dari jumlah mikroba yang ada dan menambah efek korosi pada logam menjadi lebih besar.

Pertumbuhan dan pengumpulan koloni mikroba dan pengendapan scale dari aktifitasnya biasa terjadi pada jalur pipa transport / sales gas pipe line.Tindakan yang harus dilakukan untuk mengatasi adanya potensi potensi korosi tersebut adalah dengan pembersihan jalur pipa dan perawatan secara intesif. Dalam industri perminyakan proses pembersihan pipa dari endapan menggunakan teknik yang di namakan pigging. Pigging tersebut dilakukan dengan cara memasukkan alat pigging seperti styrofoam atau jenis yang lain yang berfungsi untuk membersihkan endapan.

\section{Pengamatan efektivitas inhibitor}

Hasil analisa efektivitas inhibitor yang dilakukan pada 4 titik pengambilan sampel 001, 002, 003, 004 yang dilakukan uji korosifitas tanpa inhibitor dan dengan inhibitor. Hasil pengamatan dari sampel sebelum penambahan inhibitor terlihat adanya peningkatan nilai korosi berbanding lurus dengan waktu.

Hal tersebut di sebabkan tanpa adanya penghambat dalam proses elektrokimia maka proses korosi berjalan. Efisiensi dari inhibitor terjadi penurunan nilai dan efisiensi sebesar $58.67 \%$ pada $150 \mathrm{ppm}$, lebih tinggi dari konsentrasi $50 \mathrm{ppm}$ dan $100 \mathrm{ppm}$ terlihat pada Gambar 2.

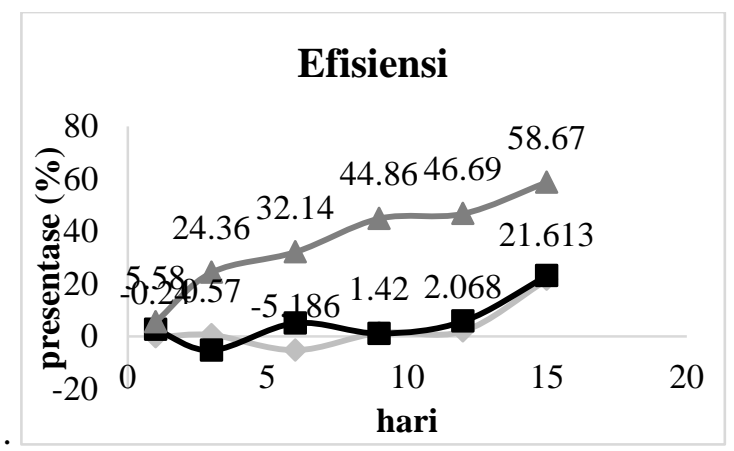

Gambar 2. Grafik hubungan antara waktu dengan persentase korosi pada titik sampel injeksi SCP 001.

Pada titik sampel pertama seharusnya didapatkan efisiensi yang tinggi dari faktor titik injeksi lebih dekat. Kurangnya efisiensi tesebut di pengaruhi oleh kecepatan dan turbulensi gas alir. Jalur injeksi pada sampel pertama terletak pada pipa pengumpul yang terdiri dari beberapa jalur dengan aliran yang berbeda.

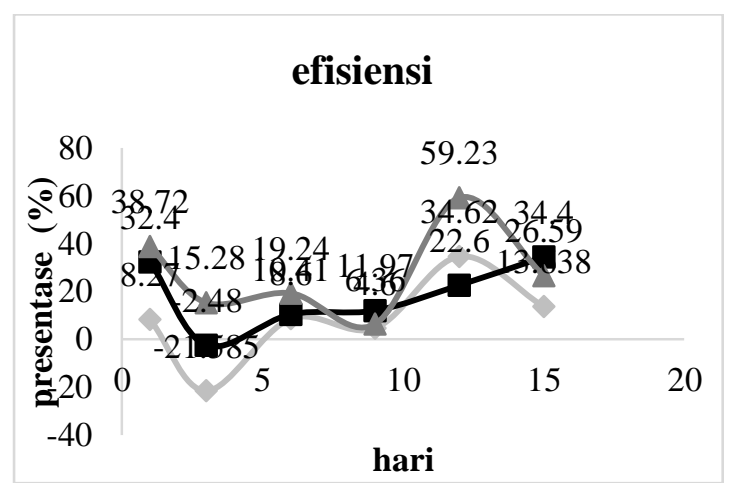

Gambar 3. Grafik hubungan antara waktu dengan persentase korosi pada titik sampel injeksi SCP 002

Dari pengujian efisiensi korosi pada titik kedua terlihat adanya penurunan setelah penambahan inhibitor, sehingga dapat didefinisikan bahwa terjadi efek inhibisi pada korosi. Efisiensi pada sampel ke-2 pada Gambar 3, didapatkan nilai 59.3\%, adsorpsi pada inihibitor pada awal terlihat sangat rendah dengan penurunan efisiensi yang cukup besar. Dengan hasil tersebut pada titik sampel 002 dimungkinkan terjadi proses korosi karena proses inhibisi yang tidak maksimal.

Gambar 4 menunjukakan efisiensi mencapai $76.67 \%$ pada penambahan inhibitor $150 \mathrm{ppm}$. Hal ini bisa sebabkan karena gangguan dari proses korosi $\mathrm{CO}_{2}$ terlarut dalam fluida terkondensasi dalam hal ini berjumlah lebih sedikit dari titik sampel yang lain.

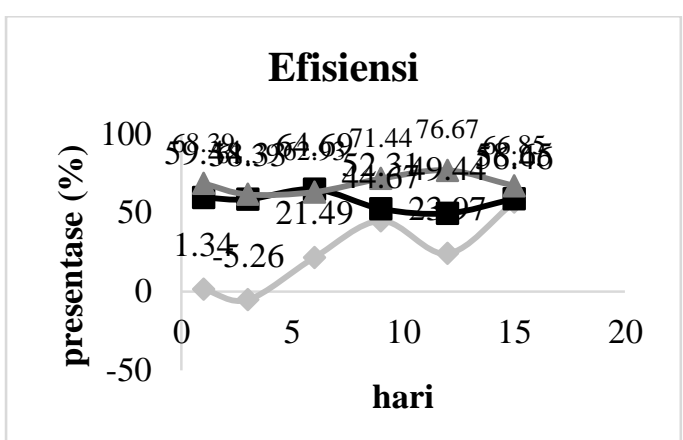

Gambar 4. Grafik hubungan antara waktu dengan persentase korosi pada titik sampel injeksi SCP 003 


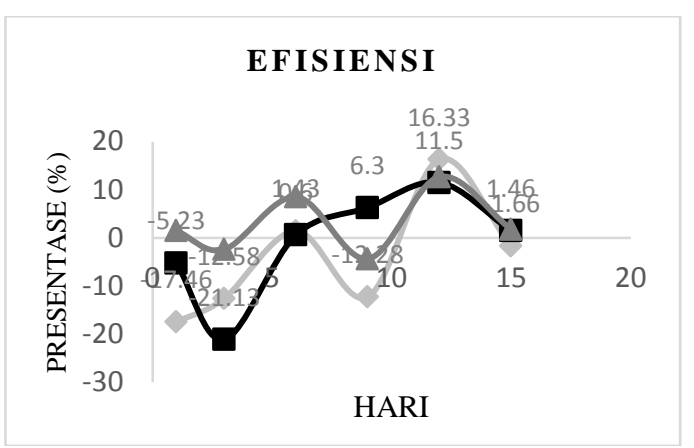

Gambar 5. Grafik hubungan antara waktu dengan persentase korosi pada titik sampel injeksi SCP 004

Berdasarkan Gambar 5 terlihat nilai efisiensi yang tidak konstan selama waktu yang di berikan. Perbedaan lokasi dan faktor fluida dalam hal ini dapat kita lihat dari gambar diatas. Pada titik sampel 004 merupakan titik yang memiliki jumlah fluida terkondensasi lebih besar. Jumlah kondesasi yang lebih besar akan menambah jumlah ion $\mathrm{CO}_{3}^{-}$dan $\mathrm{Cl}^{-}$ menjadi lebih besar. Jumlah inhibitor yang tidak seimbang dengan jumlah ion yang teradsorpsi menjadikan efek dari inhibisi menjadi tidak stabil.

Efek penambahan penghambat korosi tidak begitu besar pada tiap titik uji yaitu sample 001, 002, 003 dan 004 efisiensi inhibisi korosi yang bisa mencapai $90 \%$ setelah 5 jam kontak langsung dengan permukaan logam. Dalam uji coba gas alir pada menurut Osokogwu U, Oghenekaro 2012, efektifitas imidazoline surfactant mencapai $90 \%$ pada $1000 \mathrm{ppm}$.

Pengaruh suhu dan lingkungan menurunkan fungsi dan efek adsorpsi dari penghambat itu sendiri. Efektifitas penghambat korosi amonium kuartener sangat bergantung pada kondisi suhu pada suhu di bawah $25^{\circ} \mathrm{C}$, inhibitor mencapai efisiensi $80 \%$ sementara pada suhu yang lebih tinggi efisiensi inhibitor hanya mencapai 40\% (Malik, 2001) Penggunaan surfaktan ammonium meningkatkan nilai penghambatan korosi pada suhu 45- $60 \mathrm{C}^{\mathrm{o}}$ (Dahan dkk, 1999). Dari data pengambilan pada suhu 40Co dimana efeisiensinya dibawah efisiensi pada titik maksimal. Dalam hal ini kompleksitas faktor yang mempengaruhi selama proses korosi seperti faktor lingkungan, seperti $\mathrm{pH}$, laju alir berpengaruh terhadap efektifitas dalam penghambatan laju korosi (Nesic dan Postlethwaite, 2015). Ketidakstabilan jumlah inhibitor yang masuk kedalam sistem juga mempengaruhi efektifitas adsorpsi antara inhibitor imidazolin dan permukaan logam (Khavashar dkk, 2007). Formasi dari air yang di hasilkan oleh produksi gas sangat berbeda dengan formasi air tanah. Air formasi dari produksi gas memiliki kandungan chloride dengan kadar lebih tinggi. Kandungan chloride yang cukup tinggi dalam formasi fluida dapat menggangu kestabilan adsorpsi inhibitor dengan logam (Uhlig dan Morrill, 1941). Kenaikan suhu dapat meningkatkan nilai korosi untuk fluida dengan kandungan chloride, pada suhu kamar sampai pada suhu optimum $90 \mathrm{C}^{\mathrm{O}}$ nilai korosi meningkat dan menurun pada Titik didihnya (Uhlig dan Morrill, 1941). Peningkatan korosi tersebut menyebabkan penurunan efisiensi dari inhibitor. Seperti terlihat pada Gambar 5 nilai korosi tidak stabil yang dimungkinkan adanya gangguan dari ion choride dalam fluida. Dalam fluida chloride penggunaan kombinasi dalam inhibitor sangat di sarankan untuk mengoptimalkan efisiensi dari inhibitor dalam fluida (Ardagh dkk, 1933)

\section{KESIMPULAN}

Berdasarkan metode yang telah di lakukan yaitu dengan deteksi ER dengan variasi konsentrasi inhibitor pada $50 \mathrm{ppm}$ sampai dengan $150 \mathrm{ppm}$, nilai efisiensi inhibisi terbaik pada konsentrasi inhibitor sebesar 150 ppm yaitu $76.67 \%$.

Dari pengujian korosi pada jaringan pipa dengan menggunakan inhibitor Imidazoline yang telah dilakukan, maka disimpulkan bahwa inhibitor imidazoline dapat digunakan dengan konsentrasi penambahan lebih dari 150 ppm.

\section{DAFTAR PUSTAKA}

Ardagh EGR , Roome RMB , Owens HW, (1933) "Mechanism of Corrosion of Iron in Sodium Solution" Industrial Engineering Chemistry vol 25 (10) hal 1116-1121;

Dahan EHA, Mohamed T.Y.S, Abo El-Enin S.A, (1999), "Efficient quaternary ammonium salt as corrosion inhibitor for steel pickling in sulphuric acid 1media", Anti-Corrosion Methods and Materials, Vol. 46 Iss 5 hal $358-363$;

Dennis E, Garrelfs J, 2014, "Corrosion of Iron by Sulfate-Reducing Bacteria: New Views of an Old Problem Appl". Environ. Microbiol. Vol. 80 no. 412261236; 
Ikeda A, Mukai S, Ueda M, (1985) "Corrosion Behavior of 9 to $25 \%$ Cr Steels in Wet $\mathrm{CO}_{2}$ Environments", CORROSION. 41(4):185-192;

Jovancicevic V, Ramachandran S., Prince P., (1999), "Inhibition of Carbon Dioxide Corrosion of Mild Steel by Imidazolines and Their Precursors", CORROSION. 55(5):449-455;

Kermani, MB, Morshed A., (2003), "Carbon Dioxide Corrosion in Oil and Gas Production - A Compendium", CORROSION. 59(8):659-683;

Khavasfar A, Moayed M, Jafari H, (2007), “An Investigation on the Performance of an Imidazoline Based Commercial corrosion Inhibitor on $\mathrm{CO}_{2}$ Corrosion of Mild steel" , JE TRANSACTIONS A: Basics Vol. 20, No. 1 hal. 35-44;

Malik H, (2000), "Effect of $\mathrm{pH}$ on the corrosion inhibition of mild steel in $\mathrm{CO} 2$ saturated brine solution", Anti-Corrosion Methods and Materials, edisi 47 hal. 88-93;

Nesic S, J Postlethwaite, SO, (1996) "An electrchemical Model for Prediction of corrosion of Mild steel in aqueous carbon dioxide", International Journal Corrosion science edisi 52 revisi4, 280294, University of Queenland, Brisbane;

Uhlig HH, Morrill MC, (1941), "Corrosion of 18-8 Stainless Steel in Sodium Chloride Solutions", Industrial Engineering Chemistry vol 33 (7) hal 875-880. 